\title{
PUBLIC REGULATION AND ADMINISTRATION IN THE SPHERE OF SMALL BUSINESS
}

\author{
Kostiantyn Shaposhnykov' ${ }^{1}$, Oleh Holovko
}

\begin{abstract}
The article highlights the system of public regulation and administration of the small business. The purpose of the article is to study features of public regulation and administration in the sphere of small business and to form conceptual foundations of its improvement. The subject-matter of the study is the theoretical and practical aspects of public regulation and administration of small business in the country. In the course of research, the following methods are used: dialectical - to identify factors and system of public regulation, system analysis to determine the essence of state support for the country's economy, graphical analysis - to present schematically the general theoretical and practical results of the study, logical generalization of results - to substantiate the basic prerequisites for the formation of state support system for small business. The essence and importance of public regulation and administration in the sphere of small business are studied. Index of Economic Freedom is analysed and the ranking of countries by the ease of doing business is built. It is determined that the current political and economic situation in Ukraine is unfavourable, which considerably slows down the development of small business. Main prerequisites for the formation of the system of public regulation and administration of small business are revealed and justified: improving the legal framework to facilitate the development of small business; providing a system of benefits for small business; development of business environment infrastructure; expansion of small and large business cooperation; state support for the development of factoring and leasing activities; providing financial and credit and also investment support to the business sector; management and information support.
\end{abstract}

Key words: public regulation, administration, small business, development, state support.

JEL Classification: M20, H70, Z18

\section{Introduction}

One of the priority tasks of public policy in all countries is to support the development of small and medium business. It is a small business that is very important in providing a competitive environment, economic strength, increasing the employment level of the population and, therefore, reducing social tensions in society. So, the issue of regulation, administration, and support of small business development in developed countries of the world are decisive in the interaction of interests of the state and interests of small and medium business. In Ukraine, unfortunately, a small business cannot yet be identified as an important sector of the national economy. Taking into account the current transformation processes in the country's economy and the features of the formation of small business in our country, comprehensive state support to the development of this sphere in ensuring stabilization and socio-economic development of society is required.

\footnotetext{
Corresponding author:

${ }^{1}$ Black Sea Research Institute of Economy and Innovation, Ukraine.

E-mail: k.s.shaposhnykov@gmail.com

ORCID: https://orcid.org/0000-0003-0640-9934

${ }^{2}$ Black Sea Research Institute of Economy and Innovation, Ukraine.

E-mail: o.p.golovko@gmail.com
}

\section{Analysis of recent research and publications}

World economic science pays considerable attention to the study of the sphere of public regulation of smallbusiness as one of the natural factors of the country's socio-economic development. An important contribution in the theory of entrepreneurship is made by A. Smith, R. Cantillon, J. Thünen, F. Knight, J.B. Say, A. Marshall, M. Weber, W. Sombart, P. Drucker, B. Karlöf, B. Szántó. Among the domestic researchers of various aspects of small business development, we should mark H. Bilous, B. Burkynskyi, A. Butenko, Z. Varnalii, V. Zhykharova, I. Komarnytskyi, M. Krupka, V. Kuznietsov, Ye. Lazarieva, I. Lemeshevskyi, V. Lysiuk, V. Liashenko, V. Onyshchenko, L. Nikolaiev, M. Syzonenko, D. Stechenko, O. Tymchenko, N. Shlafman. Issues of regulation and development of small business are highlighted in papers of foreign scientists: A. Müller, J. Reid, M. Porter, H. de Soto, G. Stigler, E. Chamberlin, O. Auzan, and others. Among the domestic scholars and researchers of public regulation and administration of small business development, B. Adamov, V. Vyhovska, 
L. Vorotina, Yu. Ivanov, M. Kyzym, V.Liashenko, V. Orlova, N. Poltarak, O. Shpychak, L. Cherniuk, M. Chumachenko, V. Yurchyshyn, and others should be noted. In their works, they studied theoretical, methodological, and practical aspects of the essence and condition of small business, identified problems of regulation of its development. However, the issue of public regulation and administration of small business development in Ukraine remains extremely urgent for the modern stage of reformation of market relations in the country's economy. Modern organizational, legal, economic conditions of small business development require an in-depth study to ensure the socio-economic growth of the country.

\section{Essence and importance of public regulation and administration in the sphere of small business}

In the current economic environment, public regulation and support to small businesses in Ukraine are an important prerequisite for its intensification in overcoming crisis phenomena and ensuring economic development. In general, in the papers written by O. Prutska and Yu. Yarova, state support to the economy is determined within the public regulation as "a way of influencing business entities aimed at solving certain tasks of economic development through the use of a set of instruments and forms" (2013). Researchers V. Laptiev and S. Zankovskyi (2006) consider state support through the state regulation of the economy and define it "as a set of organizational, legal, economic, and other measures of influence on the development of economic activity and solving social problems." K. Lebodkin (2011) notes as "positive tendencies in the sphere of small business as a result of implementation of measures of its state support, among them the increase of economic entities, small enterprises, the share of small and medium-sized enterprises in the total number of business entities, the volume of manufactured and sold products by one enterprise in the small and medium business sector, as well as some negative effects, namely: low volumes of production and sale of products per one operating enterprise; reducing the share of the small business sector in the volume of products sold (services provided)".

According to the Law of Ukraine "On State Aid to Business Entities” (Zakon Ukrajiny pro derzhavnu dopomoghu subjektam ghospodarjuvannja), state aid to business entities - support in any form to business entities at the expense of state resources or local resources that distorts or threatens to distort economic competition, creating benefits for the production of certain goods or the conduct of certain economic activities.

It should be noted that the importance of public regulation increases significantly with the signing of the Association Agreement between Ukraine and the EU, in which the issue of legal regulation of state support has received considerable attention (Iristyscheva,
Krupitsa, 2014). Therefore, any state support requires spending of budgetary funds that must be used effectively and aimed at developing the country's economic potential.

In our opinion, public regulation and administration in the sphere of small business is a special type of business management relations between public authorities and local self-government and small business entities. In the current regulatory framework, there are several signs for identifying small businesses for various purposes. So, the Law of Ukraine "On State Aid to Business Entities" substantiate the legal bases of state support and regulation of small business. This Law defines the essence of a small business entity, that is, indicates which business entities belong to the category of small business entities, namely (Zakon Ukrajiny pro rozvytok ta derzhavnu pidtrymku malogho i serednjogho pidpryjemnyctva v Ukrajini):

- natural persons, registered in the established order as subjects of economic activity;

- legal entities - subjects of economic activity of any organizational and legal form and ownership, in which the average accounting number of employees during the reporting period (calendar year) does not exceed 50 people, and the amount of annual gross income does not exceed 70 million UAH.

The Commercial Code of Ukraine adopted on 09.06.2013 contains an updated classification of the small, medium, and large business entities (Part 3, Art. 55), which combines the definition of small business entities that previously existed in Art. 1 of the above law. These changes in the Commercial Code of Ukraine are made by the Law "On Development and State Support of Small and Medium Business in Ukraine" No. 4618 where (Section 5, para. 3) micro, small, and large business entities are clearly defined. Those that are beyond the above categories are classified as medium-sized enterprises. Among the small business entities, a sub-category of micro-business entities is distinguished. However, state support, in accordance with the Law No. 4618, is provided to small and medium-sized businesses that meet the criteria set out in Part 3 of Art. 55 of the Commercial Code of Ukraine (Art. 12 p. 1) (Ghospodarsjkyj kodeks Ukrajiny).

It should be noted that in Ukraine, state regulation policy of small business is characterized by considerable state intervention in small business. This is evidenced by the dynamics of the indicator of business freedom of the Index of Economic Freedom (Figure 1). When calculating the Index, 4 groups of factors are used (Indeks ekonomichnoji svobody 25 -ty richnyj vypusk): - rule of law;

- government size;

- regulatory efficiency;

- market openness.

Today, the Index of Economic Freedom is calculated for 186 countries of the world, with only 180 of them fully rated and ranked. 


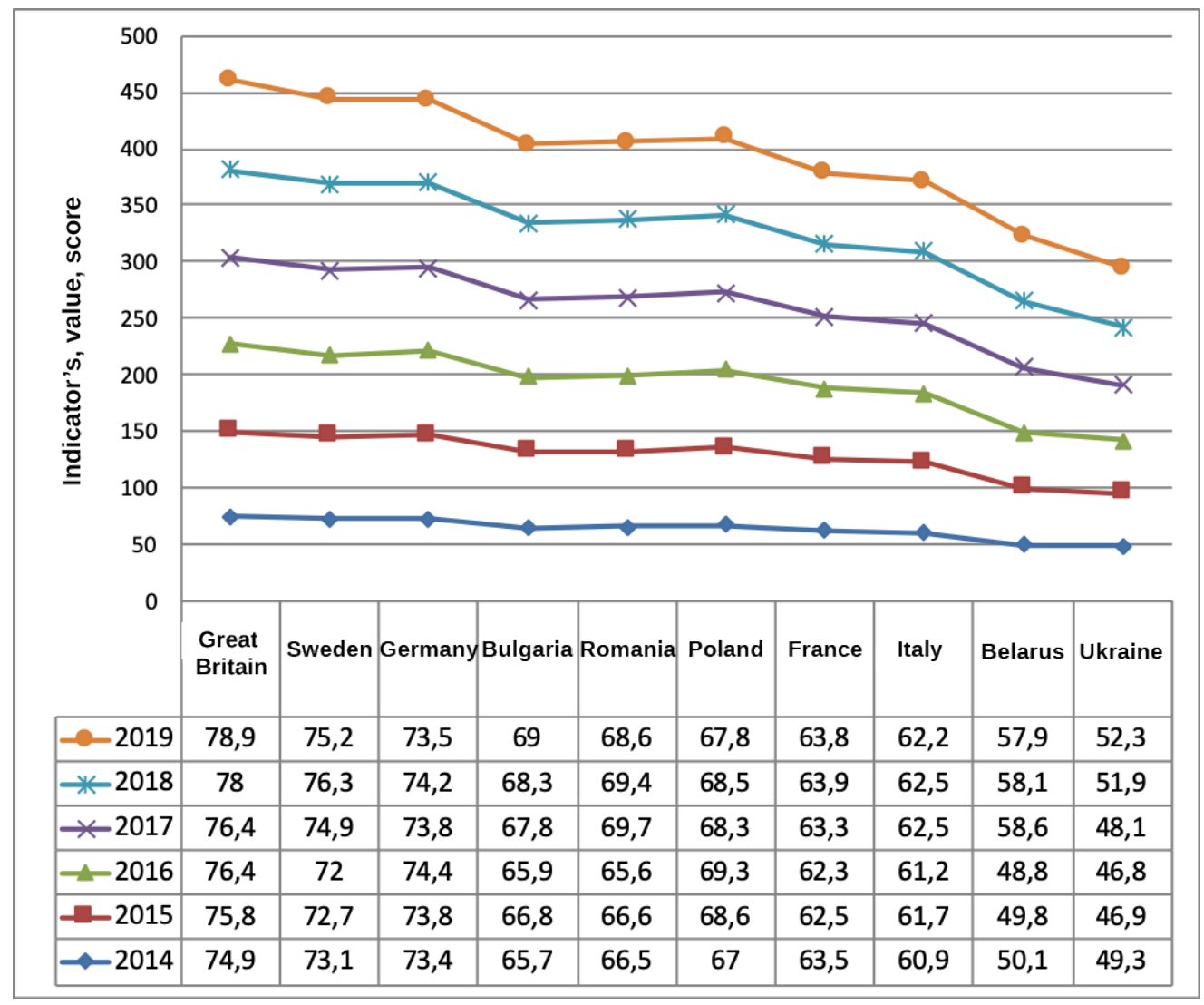

Figure 1. Dynamics of the Index of Economic Freedom for 2014-2019

During 2014-2019, the highest score of the Index of Economic Freedom in Ukraine is 52,3. Compared to the last year, some indicators are worse, namely: property rights, governmental transparency and trade freedom. Attention should be paid to the fight against corruption, the capital market development, the privatization of state-owned enterprises, and the improvement of the legal framework and the rule of law. The leading countries are Great Britain, Sweden, and Germany.

It is worth noting that the main factors of negative processes of small business are ineffective state regulation of small business activities, in particular: frequent changes in public policy that do not allow time for the entities to adapt to new economic conditions, inefficient tax policy. The issue of corruption in the public authorities is of paramount importance, as it adversely affects all areas of small business.

According to statistics, in recent years the number of small businesses per 10 thousand people in Ukraine is much lower than in European countries. In 2017, the number of small enterprises in the country was 425 units per 10 thousand people, it significantly reduced by 52 units as compared to 2010 (Derzhavna sluzhba statystyky Ukrainy). It stands to mention that this indicator in Italy - 600, in Spain - 508, in France - 478. In terms of employment for small businesses in Ukraine, it did not reach even $4 \%$ of the total population, but in
European countries, the share of employed workers is between $10-20 \%$. The volume of sales of small enterprises in Ukraine in the total volume of sales is the smallest, which is almost $25 \%$. In particular, the volume of sales in Spain, Italy, and Portugal reaches 50\% of the total sales.

Study of foreign experience in public regulation of small business shows that in many countries, various levers for supporting this sphere are widely used (Table 1) (Voloshchuk, Rakovich, Simochko, 2016). So, in Great Britain, there are programs of financial assistance to small businesses, namely: a scheme to support business creation, which provides assistance to unemployed people who intend to start their own business; loan guarantee program; programs to assist young people in creating and expanding their businesses; programs to assist local authorities in developing small business (Jevropejsjka khartija malykh pidpryjemstv). Income tax rates for small businesses have been reduced up to $27 \%$, while for other businesses it has been reduced to $35 \%$ and taxes on investments in new small business areas, especially those associated with high risk. Support for small enterprises takes place at the expense of local business agencies, job centres, utility associations, and initiative groups and services of small firms.

Small business support in European countries is taking place through special programs implemented 
Vol. 5, No. 4, 2019

Baltic Journal of Economic Studies

Table 1

Characteristics of state support systems for small business

\begin{tabular}{|c|c|c|c|c|}
\hline $\begin{array}{l}\text { Country/ } \\
\text { indicator }\end{array}$ & Financing & Taxation system & $\begin{array}{l}\text { Opening } \\
\text { and closing } \\
\text { conditions }\end{array}$ & $\begin{array}{l}\text { Organizations that support and } \\
\text { regulate small business }\end{array}$ \\
\hline Ukraine & $\begin{array}{l}\text { Limited financial resources for small } \\
\text { business development. } \\
\text { Ineffective credit and state financial } \\
\text { support policy for small businesses. }\end{array}$ & High tax rates & $\begin{array}{l}\text { The opening } \\
\text { system is simple }\end{array}$ & $\begin{array}{l}\text { Ukrainian Fund for Entrepreneurship } \\
\text { Support, Small Innovative Business } \\
\text { Support Fund, Regional Fund for } \\
\text { Entrepreneurship Support }\end{array}$ \\
\hline USA & $\begin{array}{l}\text { Lending with low-interest rates by } \\
\text { programs: } \\
\text { SBA 7(a) Loan, The } 504 \text { Loan Program. } \\
\text { Loan program for small businesses that are } \\
\text { not eligible for loans through conventional } \\
\text { lending channels for up to } 10 \text { years. }\end{array}$ & $\begin{array}{l}\text { Taxes depend on } \\
\text { enterprise size }\end{array}$ & $\begin{array}{l}\text { Support to } \\
\text { entrepreneurs } \\
\text { and simplified } \\
\text { startup process }\end{array}$ & $\begin{array}{c}\text { Small Business Administration, Small } \\
\text { Business Development Centers, } \\
\text { California Association for Local } \\
\text { Economic Development; Service Core } \\
\text { of Retired Executives; Centers for } \\
\text { International Trade Development }\end{array}$ \\
\hline Germany & $\begin{array}{l}\text { Programs that facilitate access to } \\
\text { capital and new technologies, granting } \\
\text { preferential loans for small business } \\
\text { development in the following fields: } \\
\text { scientific development, construction, } \\
\text { production, improving the environmental } \\
\text { situation in the country. } \\
\text { Lending with low-interest rates and } \\
\text { extending the use of finance up to 5-15 years. }\end{array}$ & $\begin{array}{c}\text { Too high tax rate. } \\
\text { Grants for } \\
\text { agriculture. }\end{array}$ & $\begin{array}{l}\text { The complicated } \\
\text { and long } \\
\text { registration } \\
\text { procedure }\end{array}$ & $\begin{array}{l}\text { Youth Entrepreneurship Strategy } \\
\text { in Wales, EU programme for the } \\
\text { Competitiveness of Enterprises and } \\
\text { Small and Medium-sized Enterprises, } \\
\text { SMEs), ERP (European Recovery } \\
\text { Programme, Coparion for young firms, } \\
\text { INTERREG - support for regional } \\
\text { projects }\end{array}$ \\
\hline
\end{tabular}

in the EU countries due to comprehensive support at the state level. Within the theory of support, we substantiate the legal aspects of state support for small business in Europe and Ukraine. The legal aspects of supporting small and medium-sized businesses at the supranational level are defined by the Small Business Act for Europe (Akt malogho byznesa dlja Evropy), which is based on the European Charter for Small Enterprises and is the first European initiative to ensure the sustainable growth and expansion of small and medium-sized enterprises (SMEs) (Jevropejsjka khartija malykh pidpryjemstv).

As a result of this document, new opportunities have opened up for SMEs to sell products to foreign markets and prospects for expanding international relations, forming the legal framework of the country.

The issue of support and development of small business in Europe was identified in 2009 by the Competitiveness Council in the document "Conclusions on the small business act", which identified the following priority areas of economic development of small business: simplification of access to finance, facilitating market entry, creating an enabling environment for the effective development of the business sector (Conclusions on the review of the "Small Business Act" for Europe).

In 2010, another economic development strategy for small business was adopted - "Europe 2020: a strategy for smart, sustainable and inclusive growth" that set out the following strategic goals for EU development: improving employment, scientific and technological development, improving education and science, increase of social activity and well-being of the population (Jevropa-2020 strateghija).
This document has become the driving force for creating and promoting the necessary levers of economic, social, regional policy and has made it possible to reorient existing small business development measures to the most effective and promising ones.

Let us consider an analysis of the level of business development of countries in the world rankings on the ease of doing business (Figure 2). According to the Doing Business-2019 ranking, Ukraine occupies a positive position, having risen for 4 years by 12 positions (Doing Business in Ukraine). The rating is compiled by the World Bank and evaluates the following areas: business registration, building permit, connection to electrical systems, property registration, obtaining loans, protection of minority investors, taxation, international trade, contract execution, insolvency resolution (Doing Business in Ukraine). The political and economic situation in the country is unfavourable, which significantly hampers the development of small business. It is worth noting that an important consequence of the existing problems of small business development in Ukraine is the growth of the level of shadow economy every year.

To improve the business environment in Ukraine, the European Bank for Reconstruction and Development (EBRD) is pursuing an active financial policy in Ukraine, in particular, by funding 329 projects. The EBRD has already invested 9.64 billion USD in Ukraine. Since 2015, the EBRD and the EU have jointly launched a project to support small and medium-sized businesses in Ukraine, Georgia, and Moldova. Funding is provided through a network of regional banks to maximize the approximation of funds to their immediate recipients. 


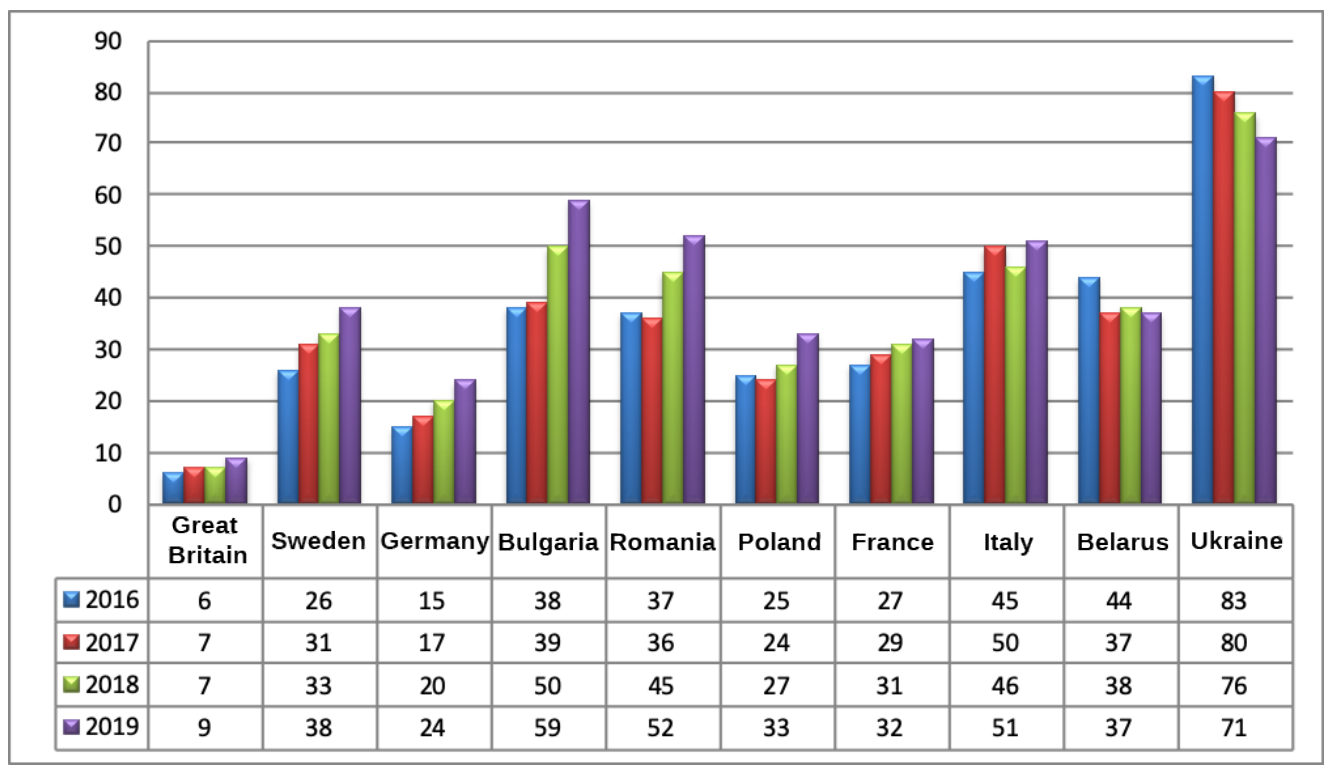

Figure 2. The Ease of Doing Business ranking of countries

EU Support to Ukraine to Re-launch the Economy program, which is oriented to 2016-2020 with an estimated budget of 95 million EUR, is aimed at supporting small and medium-sized businesses in the country's regions through technical assistance and advice on business deregulation and improvement of national and regional business development programs, the establishment of regional business support centres, which will contribute to economic growth and employment, creation of an export-oriented economy. It also envisages the development of a loan-guarantee instrument to be issued by commercial banks.

It is worth noting that according to the National Program on Promotion of Small Business Development, financial and credit support for small business is a system of measures of a certain credit-guarantee mechanism that work for the development of small business and self-employment of the population (Zakon Ukrajiny pro Nacionaljnu proghramu spryjannja rozvytku malogho pidpryjemnyctva v Ukrajini).

In order to intensify the activity of the small business, it is necessary to form a comprehensive mechanism for the development of public regulation and administration of the small business sector (Figure 3 ). The main factors supporting small business include legal framework, tax regulation, support infrastructure for small businesses, as well as management and information support (Grishina, Butenko, Grishina, 2014).Supportfunds, governingbodies, and international institutions are the main institutional components of state support for small business.

Thus, the main tasks of public regulation and administration of the sphere of small business should be the following:

- improving the legal framework for the development of small businesses;
- benefits systems for small business entities in the country;

- development of infrastructure for ensuring the functioning of the business environment;

- development of cooperation of small and large business; - state support for the development of factoring and leasing activities;

- providing financial and credit and investment support to small and medium business;

- development of self-employment of the public;

- management and information support in the sphere of small business.

\section{Conclusions}

Based on the results obtained, the author concluded that for the effective public regulation and administration in the sphere of small business, favourable conditions are required for the development of activity of small business structures, which are implemented through support funds, governing bodies, and international institutions, as well as support of business incubators, technoparks, technopolises, and clusters. The conducted analysis of foreign experience shows that public regulation of small business is closely associated with other areas of socioeconomic development of the country, namely, new job formation, growth and development of the economy, and increase of the country's competitiveness. When forming support programs for small business, public authorities and local self-government bodies should take into account the interests of employed workers, the degree of their loyalty to market relations. Creation of favourable legal, organizational, and economic conditions for the development of small business should become one of the main goals of state policy. 


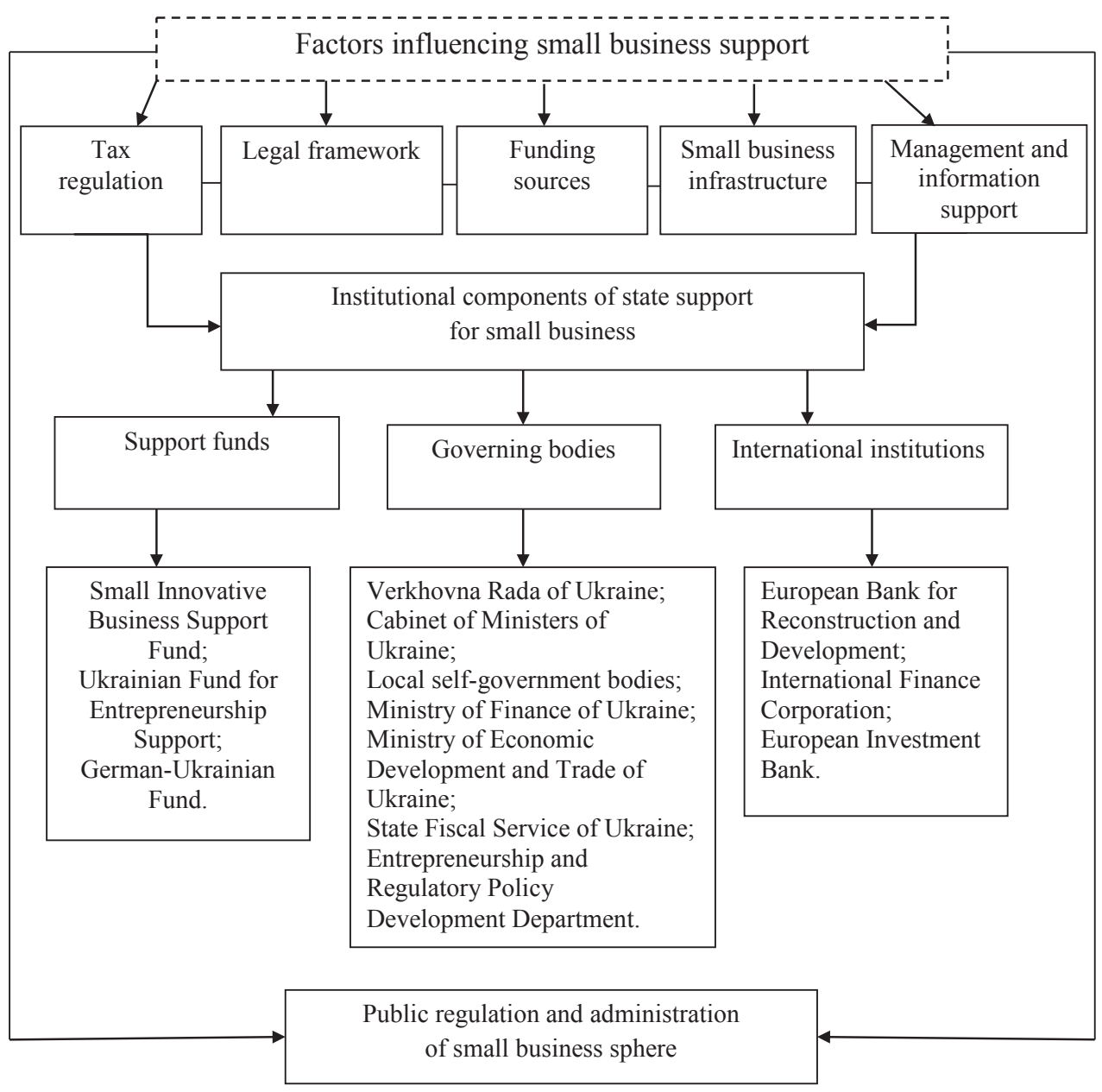

Figure 3. Mechanism of development of public regulation and administration of small business sphere

\section{References:}

Akt malogho byznesa dlja Evropy [A Small Business Act for Europe]. Retrieved from: http://eur-lex.europa.eu/ LexUriServ/LexUriServ.do?uri=COM:2011:0078:FIN:en:PDF

Conclusions on the review of the "Small Business Act" for Europe. Retrieved from: http://www.en.bmwfw.gv.at/ Enterprise/Documents/SBA\%20Review\%20Council\%20Conclusions.pdf

Derzhavna sluzhba statystyky Ukrainy [State Statistics Service of Ukraine]. Retrieved from: http://www.ukrstat.gov.ua/ Doing Business in Ukraine. Retrieved from: http://www.doingbusiness.org/data/exploreeconomies/ukraine\#close Ghospodarsjkyj kodeks Ukrajiny vid 04.03.2015 [Economic Code of Ukraine].

Grishina, N. V., Butenko, A. I., \& Grishina, L. O. (2014). Potencial malogho pidpryjemnyctva jak faktor zabezpechennja rozvytku konkurentospromozhnykh ghaluzej: reghionaljnyj aspect [Potential of small business as a factor in ensuring the development of competitive industries: the regional aspect]. Economist, 6, 20-24.

Information from the Verkhovna Rada of Ukraine (BPD) dated January 16, 2003 No. 436-IV, 2003, No. 18, No. 19-20, No. 21-22, p. 144. Retrieved from: https://ueff.org/images/UEFF/content/indices/heritage/heritage_ index_2019.pdf

Iristyscheva, I. O., \& Krupitsa, I. V. (2014). Derzhavne reghuljuvannja socialjnoji orijentaciji nacionaljnoji ekonomiky [State regulation of the social orientation of the national economy]. Scientific herald of the Kherson State University, 7(1), 198-202.

Jevropa-2020 strateghija [Europe-2020 strategy].Retrieved from: http://ec.europa.eu/europe2020/index_en.htm Jevropejsjka khartija malykh pidpryjemstv [European Charter for Small Enterprises]. Retrieved from: http:7/zakon4.rada.gov.ua/laws/show/994_860

Konkurentospromozhnistj malogho pidpryjemnyctva - faktor socialjno-ekonomichnogho rozvytku reghionu [Competitiveness of small business is a factor of socio-economic development of the region]. Collection of scientific works of the National University of Shipbuilding, 2, 25-30.

Laptiev, V. V., \& Zankovskyi, S. S. (2006). Predprynymateljskoe (khozjajstvennoe) pravo [Business (economic) law]. Moscow: Walters Kluver. (in Russian) 
Lebodkin, K. S. (2013). Ghospodarsjko-pravova polityka shhodo derzhavnoji pidtrymky subjektiv ghospodarjuvannja [Economic and legal policy on state support of business entities]. Bulletin of the National University "Legal Academy of Ukraine named after Yaroslav the Wise, 2(13), 182-191.

Terry Miller, Anthony B. Kim, James M. Roberts, \& Patrick Tyrrell (2019). Indeks ekonomichnoji svobody 25-ty richnyj vypusk [Index of economic freedom 25th anniversary edition]. Retrieved from: https://www.heritage.org/index/pdf/2019/book/index_2019.pdf

Prutska, O. O., \& Yarova, Yu. M. (2013). Derzhavna pidtrymka pidpryjemnycjkoji dijaljnosti v aghrarnomu sektori [State support of entrepreneurial activity in the agrarian sector]. Collection of scientific works of Vinnytsia National Agrarian University, 1(76), 112-122.

Voloshchuk, N. Yu., Rakovich, S. S., \& Simochko, S. R. (2016). Derzhavne reghuljuvannja u sferi aktyvizaciji rozvytku malogho pidpryjemnyctva [State regulation in the sphere of activation of small business development]. Nikolayev National University named after V. O. Sukhomlynsky, 14, 100-105.

Zakon Ukrajiny pro derzhavnu dopomoghu subjektam ghospodarjuvannja: Zakon Ukrajiny vid 01 lypnja 2014 r. \# 1555-VII. [Law of Ukraine on State Assistance to Business Entities: Law of Ukraine dated July 1, 2014 No. 1555-VII]. Retrieved from: http://zakon2. rada.gov.ua/laws/show/1555-18

Zakon Ukrajiny pro Nacionaljnu proghramu spryjannja rozvytku malogho pidpryjemnyctva $\mathrm{v}$ Ukrajini: vid 21.12.2000 \# 2157-III [on the National Program for Promotion of Small Business Development in Ukraine: No. 2157-III dated 21.12.2000]. Retrieved from: http:// zakon.rada.gov.ua/laws/show/2157-14

Zakon Ukrajiny pro rozvytok ta derzhavnu pidtrymku malogho i serednjogho pidpryjemnyctva v Ukrajini: vid 22.03.2012 № 4618-VI [Law of Ukraine on Development and State Support of Small and Medium Enterprises in Ukraine: Law of Ukraine]. Retrieved from: http://zakon.rada.gov.ua/laws/show/4618-17 